Copyright (C) 2021 by Cherkas Global University

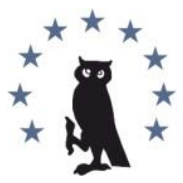

Published in the USA

Media Education (Mediaobrazovanie)

Has been issued since 2005

ISSN 1994-4160

E-ISSN 2729-8132

2021. 17(4): 632-644

DOI: $10.13187 / \mathrm{me} .2021 .4 .632$

https://me.cherkasgu.press

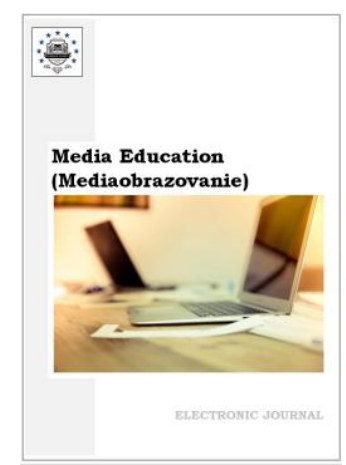

\title{
Representation Features of Historical Truth in Fiction and Documentary Cinematography, TV Reporter's Skills
}

\author{
Olga Kosachova a, * \\ ${ }^{a}$ Kharkiv State Academy of Culture, Kharkiv, Ukraine
}

\begin{abstract}
The article analyses the representation of historical and current issues in fiction and documentary cinematography. The author outlines the general complexity of the historical genre, often accompanied by criticism of the society, power structures, and institutions of the church. A dramaturgy analysis of films, as well as expressive directing and camera means and techniques, sound direction have been carried out. Special attention is paid to the analysis of methods of gathering information in documentary films: observation, working with documents, interviews, etc., inherent in the work of a TV reporter. The participatory and poetic modes of documentary are examined in detail. It was revealed that documentary films are more independent than fiction films, primarily from the budget issues and critical acclaim, therefore a store of issues covered in documentary films is much wider. The documentary cinematography is also richer by expressive means. The authors of modern historical drama create documentary-style films, unjustifiably transforming films from feature ones into a chronicle displaying a series of changing facts from the plot of the script. Suggestions have been made to revise the principles of work on the historical genre, enabling to reach a new level of development of feature films.
\end{abstract}

Keywords: fiction films, historical film, historical drama, documentary films, journalistic investigation, TV reporter.

\section{Introduction}

Revealing the historical truth by means of cinematography is a complex and multifaceted process. On the one hand, the viewer requires reliability; on the other hand, s/he is not always ready to perceive new, sometimes shocking facts about existing reality. Historical truth is typical for documentaries, but with feature films, everything is much more complicated. Any fiction film reflects real relations between people, and even fantasy has a real basis for the struggle between goodness and malice, reveals universal human values and philosophical issues that concern humanity. At the same time, the broader and more abstract the events are covered, the easier it is for the director to avoid criticism of the society, power structures, and church institutions. This raises the off-limits subjects that are undesirable for viewing by the broad masses, destroying the existing ideological doctrine and beliefs in the society. However, the question arises as to who benefits from the existing ideology - those in power or the population as a whole. Let us try to figure out in the study.

An important issue is the genre differentiation of fiction and documentary films, which fundamentally changes the purpose of art meaning and the impact goals of each individual film, in particular. For example, any sane person understands that the dark time of the Inquisition is

\footnotetext{
${ }^{*}$ Corresponding author

E-mail addresses: kosachovaolgaaleks@gmail.com (O. Kosachova)
} 
characterized not so much by the delusion and ignorance of that time as by sadism and abuse of power by the Catholic clergy. At the same time, most of the films that are concerned with this topic speculate on the theme of mysticism, showing "real" witches who send misfortunes and curses to humanity (The Last Witch Hunter, Season of the Witch, The Monk), etc. Horror films stand apart, the purpose of which is to give the viewers a thrill, leading to a shattered nervous system. Based on this, one leading genre of fiction films - historical drama and documentaries - have been chosen for this study.

\section{Materials and methods}

In the course of the study, a number of sources touches upon the issue of art criticism, in particular fiction and documentary cinematography, social communications and journalism, cultural studies, mythology and religious studies, histories of Western Europe and the USA, legislative documents, Candidate's and Doctoral theses are concerned with the representation of history in feature films etc. The empirical base of the research includes documentary and fiction historical films dedicated to topical issues of our time.

The study used the basic methods of cognition: socio-communication, axiological, culturological approaches, figurative and stylistic analysis and the structural and functional method, art criticism approach, combined with morphological analysis.

The socio-communication approach makes it possible to consider a fiction or documentary film as a socially significant message embodied in an audiovisual form, serving as an intermediary in the communication chain "author - viewer". The semiotic-hermeneutic method contributed to the analysis of coding, decoding and interpretation of inherent meanings, reconstruction of modern reality from the perspective of past events.

The figurative and stylistic analysis and the structural and functional method make it eventual to analyze films as a complex of expressive means that perform particular functions for the benefit of the functioning of the integral film system. The roles of expressive means in the general system, the interdependence of the film form and content are determined.

The axiological approach is aimed to analyze films as a set of ideas, motives, norms and ideals intended at the formation of a particular model of behavior in the viewer. An attempt is made to reveal whether directors turn to such universal values as life, health, love, education, work, creativity, or vice versa - and neglect them for the sake of the opportunistic demands of modern Western ideology.

The culturological approach puts forward the cultural and social factors in shaping public demand for historically accurate films, on the one hand, and unwillingness to perceive acute painful facts, on the other. The method of comparative analysis makes it possible to compare feature films and documentaries, united by one theme - historical truth and differing in fundamentally dissimilar methods, production technology and expressive means.

The art criticism approach, combined with morphological analysis, make it possible to analyze the dramatic foundations of fiction and documentary films, due to the genre-specific features of the audiovisual works, the author's intention and the needs of society.

\section{Discussion}

The source study analysis makes it possible to record the great interest of scientists in displaying individual historical events in feature films; however, there are not enough works on the issues of representing acute discussion angles in feature and documentary films. There is also a lack of research concerned with the modern scientific reflection on the balance and correlation of fiction and documentary films in the modern world film process.

Every director on his way is faced with a choice between art as a mirror of life and art as resources of transforming it. Perhaps, this is the fundamental difference between fiction and documentary films. Regardless of the kind of cinema, the study is guided by one of the principles of British art history specialist K.C. McKenzie, who emphasized the intellectual role in artistic creativity: “....art must do something more than give pleasure... Art is not a lollipop, or even a glass of kümmel. The meaning of a great work of art, or little of it that we can understand, must be related to our own life in such a way as to increase our energy of spirit” (Clark, 1960: 15).

One of the problems of feature films is financing, which makes feature films not free and more dependent. The famous author of BBC documentaries, M. Rabiger, characterizes this problem as follows: "Just imagine how many major works of literature would still exist if J. Austen, 
G. de Maupassant, D. Lessing, J. Updike and other writers whose specialty is revealing the significance in unremarkable lives were forced to apply for huge sums of corporate money before writing a single word. Our libraries would turn into echoing vaults containing only supermarket novels" (Rabiger, 1987: 171-172). This study by M. Rabiger Directing the Documentary demonstrates to the reader an amazing balance between the social and creative role of documentary and the technical issues of filmmaking.

Another source that served as a conceptual basis for the study is the work of R. McKee Story: Substance, Structure, Style and the Principles of Screenwriting, an individual place of which is given to the historical genre. McKee compares the history of mankind to a treasure chest, which is sealed and the warning inscription on it: "What is past must be present. A screenwriter isn't a poet hoping to be discovered after he's dead. He must find an audience today. Therefore, the best use of history, and the only legitimate excuse to set a film in the past and thereby add untold millions to the budget, is anachronism - to use the past as a clear glass through which you show us the present" (McKee, 1997: 83). Turning to historical (or up-to-date) subject-matter in cinema contains many risks and dangers, echoing one of the most difficult genres of analytical journalism investigative reporting, which is addressed to the past or the present.

Of particular interest in the context of this study are the publications of the world's leading scientists dedicated to the development of documentary films as a means of not only covering, but also solving urgent social problems: racial and economic injustice (Canella, 2017); environmental protection (Yeo et al., 2018); global warming (Bieniek-Tobasco et al., 2020); racism and women's rights (Nakamura, 2020).

A separate place among these publications belongs to the study L. Nakamura Feeling good about feeling bad: virtuous virtual reality and the automation of racial empathy (Nakamura, 2020), dedicated to the phenomenon of empathy in documentary films. She explores an important contradiction: on the one hand, empathy is an important means of keeping the viewer interested. But, on the other hand, empathy as such without concrete actions is not capable of leading to constructive changes in society: "idea of compassion means that it is dangerously overvalued as a way of addressing other people's suffering... Feeling takes the place of doing precisely because there seems to be no viable liminal space between the two... The pleasures of toxic embodiment offered by witnessing racial suffering in VR extend these precarious conditions of life" (Nakamura, 2020: 61).

This problem was raised by Nietzsche in his work Thus Spoke Zarathustra: A Book for All and None (Nietzsche, 1883): "how nicely can doggish lust beg for a piece of spirit, when a piece of flesh is denied it! Ye love tragedies and all that breaketh the heart? But I am distrustful of your doggish lust. Ye have too cruel eyes, and ye look wantonly towards the sufferers. Hath not your lust just disguised itself and taken the name of fellow-suffering?” (Nietzsche, 1883).

These statements make it necessary to consider the problematic of documentaries from a different side - what caused the viewer's interest in up-to-date films - voluptuousness from the sight of other people's suffering or a sincere desire to help.

An important block of publications become articles devoted to the development of modern media, in particular, the convergence issue, the media influence on the results of film distribution (Anderson-Lopez et. al., 2021; Bergland et al., 2018; Habel et. al., 2018; Perreault et al., 2019; Tefertiller et al., 2020).

For instance, P. Habel in the article News and information leadership in the digital age (Habel et al., 2018) raises the problem of the elites' role of forming the information agenda: "when members of elite presses such as The New York Times or The Wall Street Journal publish news and information about an event or issue, other journalists perceive the story to be important. In this framework, journalists are attuned to the gatekeeping behaviors of their colleagues at established news outlets, and they use their peers' assessments routinely as a guide for their own gatekeeping choices" (Habel et al., 2018: 3). This result of the study cannot be ignored, because it also applies to taboo topics in cinema, which will be discussed in this article.

One of the more conceptual studies is the article J. Miranda-Gable Analytical Model of Transmedia Storytelling Ecosystems in Audiovisual Fiction: The Spanish Model of The Ministry of Time (Miranda-Galbe et al., 2021), dedicated to the global problem of transmedia narratives in the modern communication society. According to the author: "The quantity of information, the audience is exposed to through different mediums to a vast quantity of information allows the follower base of these vast universes to engage with the story more profoundly than a single-media project" (Miranda-Galbe et al., 2021: 3). 
Within his model of transmedia storytelling, the author presents narrative systems over the transmedia universe, which reveal the capacities and degrees of interaction between different media. His diagram allows to mark and analyze the place of modern fiction and documentary cinema in the global socio-communicative space.

This study also viewed articles on various aspects of documentary cinema: technologies VR (Engberg et al., 2020), conceptual video (Sheehan, 2019), travel films (Courtney, 2018). Of interest were also publications devoted to different film directors' styles in creating a documentaries in the context of the national aspect: Latin America, Pan-American Union (Fox, 2018), Galicia (Spain) (Amago, 2018), Japan (Jesty, 2019; Miyao, 2019).

Also in the process of the study, the problems of the evolution and expressive means of feature films were considered: (Betancourt, 2018; Cashman, 2019; Kretz, 2019; Ness, 2021).

The problem of revealing the historical truth is revealed in article W.B. Robison Lancastrians, Tudors, and World War II: British and German Historical Films as Propaganda, 1933-1945 (Robison, 2020). The author explores the phenomenon of propaganda in fiction films, and also proposes his own approach to the study of historical films. W.B. Robison notes the relativity of the concept of "propaganda", which can be used both for good and for harm. On the one side, "The best art is that which speaks to the best in humanity and elicits the best behavior" (Robison, 2020: 20), despite the historical accuracy. On the other side: "All historical films would be better if they paid more attention to historicity" (Robison, 2020: 20), notes the author. Many directors can justify historical inaccuracies with statements about the loss of most of the sources of the reflected era, however, W.B. Robison quite rightly finds this justification unconvincing and notes: "Good historians use a multiplicity of sources, approach them with critical skepticism and an awareness of how and why they were produced, and acknowledge when they speculate" (Robison, 2020: 21).

It should be noted that within the framework of this study, articles were analyzed on the social and democratic foundations of society, of which the study S. Freeman Democracy, Religion \& Public Reason (Freeman, 2020) should be noted. The author argues: "State endorsement of Christianity or religion in general calls into question the political equality of those who reject it" (Freeman, 2020: 37). Despite the fact that religion is formally separated from the state, its influence on the democratic freedoms of citizens is global.

Describing the foundations of democracy, S. Freeman approves: "A convention of democracy is that government should promote the common good. Citizens' common good is based in their shared civil interests, including security of themselves and their possessions, equal basic liberties, diverse opportunities, and an adequate social minimum. Citizens' civil interests ground what John Rawls calls "the political values of justice and public reason" (Freeman, 2020: 37). However, the analysis of the empirical base (films) in this article proves that the concepts of "democracy" and "religion", unfortunately, are sometimes mutually exclude each other, entering into a uncovered conflict. So, sometimes, the manipulation of church dogmas by immoral individuals leads to disastrous consequences.

The aim of the article is to reveal the features of the representation of historical truth in fiction and documentary films, the skills of a TV reporter.

\section{Results}

Let us consider the ways of revealing the historical truth in fiction films. Investigative film Spotlight focuses on the events surrounding the Catholic sexual harassment scandal in Boston that led to the resignation of Cardinal Bernard Francis Law. The new editor-in-chief of the daily newspaper The Boston Globe invites reporters of Spotlight department to tackle the subject of child sexual abuse in churches, leading to an investigation that, step by step, uncovers new dimensions of criminal activity and conspiracy among priests. The film shows in detail the methods of collecting information, gaining access to documents, issues of journalistic ethics. However, in general, the film is not about the victims, but about the journalists, their contribution to the publicizing of the existing problem.

The film raises an urgent concern, but in a cold, unbiased manner. Trying to create a realistic documentary-style film, the filmmakers have minimized a store of directing and cinematography expressive means. The director did not quite succeed in emphasizing the participation of journalists in the investigative problem. For them, this is the same topic as hundreds of others that they have dealt with before, just work. The viewer sees journalists with a cake, washing dishes, 
drinking beer at a football match, playing golf, jogging, sitting freely at the table, etc. The question arises - what does this have to do with the topic? The problem under consideration serves only as a pretext for promoting the images of journalists.

In 2013, the script of the film was included in the blacklist of scripts, but in 2016, Spotlight won an Academy Awards Oscar for Best Picture and Best Original Screenplay. The resonance in the circles of church offices was avoided thanks to correctly placed accents. The screenwriter Josh Singer explained: "This story isn't about exposing the Catholic Church. We were not on some mission to rattle people's faith. In fact, Tom came from a Catholic family. The motive was to tell the story accurately while showing the power of the newsroom - something that's largely disappeared today. This story is important. Journalism is important, and there is a deeper message in the story" (Iacovetti, 2016).

The film also contains the fragments justifying child molestation in churches, in particular, the theme of homosexuality is used. One of the homosexual victims tells about his contact with the priest, when he already recognized himself as a gay: "This is the first time in my life that someone told me that it was okay to begin ... and it was a priest" (McCarthy, 2015). Such a topic leads the society away from realizing the scale of crimes against children. According to the study, the justification is the most common among priests who abuse children. One can only assume what physical and spiritual traumas of unnatural relationships are inflicted on an individual. How many physically crippled children died from trauma inflicted by stupefied perverts who hide behind God and divine prescriptions is an unpopular topic in modern media. The clergy also stubbornly "forget" that sodomy is part of a person's most serious sins and transgressions, as evidenced by the Holy Scriptures.

Another speculation of the film Spotlight is an interview scene with a journalist and a pedophile priest. A seemingly harmless church minister declares that he "never get any pleasure" in molesting the boys. He was "fooling around" (McCarthy, 2015) with them. But this wasn't violence, because he was raped himself in a childhood. This scene is not developmental, it is episodic, but it is enough to blur the theme of violence, to sow doubts about the goals and actions of such priests.

The homosexuality theme appears in the films Philomena and Doubt. The 2013 film Philomena (UK, France) by Stephen Arthur Frears successfully combines several genres: drama, comedy and road movie. The script of the film was written based on the book of the political journalist Martin Sixsmith The Lost Child of Philomena Lee and has a documentary basis. Among the issues about the enslavement of girls in asylums, the transfer of born there children to the United States, the issue of human rights, in particular the right to life, is also raised. In 2017, it was announced that a large burial of 800 children aged six to three years was found on the site of a former Catholic orphanage in County Galway, which confirmed the facts set out in the biography of Philomena Lee.

Following the format of Spotlight, Philomena is an investigation film. The protagonists are journalist M. Sixsmith and an elderly woman, Philomena, who is looking for her son. The woman's child was taken away by nuns in one of the orphanages of St. Magdalene in Ireland. 50 years later, she decides to look for him and a British journalist decides to help her in this. The film widely reveals the methods of collecting information, the interaction of the journalist and the editorial board, the journalist's dependence on the editorial board and work basically.

The film raises the issue of faith, which for many Catholics cannot be separated from the church ceremonial. The journalist is a critic and fighter for truth, who seeks to hold accountable all those involved in the transfer of Irish children to the United States. Philomena herself forgives everyone. Carrying a conciliatory message, the film received a number of film awards, including four Academy Award nominations.

The 2008 American drama film Doubt, directed by J.P. Shanley, received five Academy Award nominations. In the story, the principal of a Catholic school in the Bronx Sister Aloysius suspects one of Father Flynn's priests of corrupting a child - the first African American in their school. She has suspicions, but no clear evidence. She achieves to his dismission, but the entire film contains subtle hints of the bias and groundlessness of her suspicions.

So, in this movie, filmed as it should be in documentary-style, there are two bright artistic metaphorical moments, which actually confirm the main idea of the film. The first is Father Flynn's sermon on intolerance and gossip. He cites the example of one woman who came to confession to ask for forgiveness for spreading gossip. Then the priest told her to go home, bring out the pillow and scatter its feathers in the wind. After the woman complied with the instructions, the priest 
asked to come back and collect the feathers. The woman realized that it was impossible to fulfill, as well as to take her words back. The flying feathers scene is one of the strongest in the film.

Another scene, not even a scene, but a frame bearing a metaphorical coloration, is a frame with a strong wind that twists and lifts the leaves up and practically knocks the director, Sister Aloysius, off her feet. This is the final part of the scene where the director talks to the boy's mother. To the director's expressed suspicions, the mother replies: "So what? Some boys do not mind" and says that her son was already born with homosexual inclinations (Shanley, 2008). The strong wind, as conceived by the filmmakers, symbolizes the wrath of God, which rolled over the director for her "groundless" suspicions. At the end of the film, the director admits that she is tormented by doubts about the guilt of Flynn's father. Thus, this film, like the film Philomena, leaves hope for the justification of the institution of the church, reconciliation between the institution of the church and the parishioners, public recognition of homosexuality as an inborn phenomenon. The consensus slogan has served as the main reason for critical acclaim and numerous nominations for prestigious awards.

It often happens that the viewer is not ready for sensitive social issues: "Many contemporary antagonisms are so distressing or loaded with controversy that it's difficult to dramatize them in a present-day setting without alienating the audience. Such dilemmas are often best viewed at a safe distance in time" (McKee, 1997: 83). Therefore, conflict resolution is the only option for filmmakers for filmmakers seeking to succeed in Hollywood.

A similar situation is typical for television, which "generally avoids social criticism, no matter how well argued, unless it can be safely yoked to a famous name or a widely recognized movement. This not only serves to attract viewers, it dissociates the channel or station from responsibility for the opinions expressed" (Rabiger, 2004: 94).

Unlike the previous film, the creators of the 2002 drama film by P. Mullan The Magdalene Sisters (UK, Ireland) chose a different path - a follow-up on story of the crimes of the Catholic Church is coming from the victims themselves - the girls who were forcibly imprisoned in the Magdalene asylums. The orphanages were a network of detention and rehabilitation cenacles for the so-called "fallen women" that existed from the late $18^{\text {th }}$ century to the late $20^{\text {th }}$ century. In such asylums, also known as Magdalene laundries, the girls had to wash away their "sins" with hard work. The girls were sent to orphanages by their parents or guardians. They could be taken by them from there, but in general, the girls had no rights. Many of them worked head off there, some ventured to escape to nowhere. Over the twentieth century, more than 30 thousand girls have experienced mockery on themselves.

The film The Magdalene Sisters is based on the documentary Sex in a Cold Climate. These two films represent certain integrity, revealing the fates of four women - inmates of the Magdalene asylums. The feature film The Magdalene Sisters is a kind of reconstruction of the events described in the documentary film. At the same time, this was done not for the sake of increasing the artistic value of the film, but for the sake of demonstrating those events that it was not possible to shoot. When acquainting the viewer with one of these films, a parallel demonstration of the second film would be advisable.

Due to the realism of the displayed events, the film create such impression that the viewer is completely involved in what is happening. Despite the favorable permission for the main characters of the film - rescue from the shelter, one of the stories does not find a happy resolution. This is the story of Crispina who was separated from her child. Having been sexually abused by the priest, her presence (as a witness) has become extremely undesirable in the laundry and she was forcibly sent to an insane asylum, where her psyche is finally broken. This story line brings the film closer to such masterworks of cinema as One Flew Over the Cuckoo's Nest or Requiem for a Dream, where the destruction of the psyche, own self sometimes becomes more terrible than death.

The Irish documentary Sex in a Cold Climate (1998) gives a broader picture of reality detailing the mistreatment of "fallen women" in the Magdalene laundries in Ireland. It was produced and directed by Steve Humphries. In comparison with the fiction analogue, regarding the attitude in society towards girls who have had sex before marriage. Sexual relations before marriage in the film are equated with murder. The overwhelming role of the church in society, its unquestioning nature, the fact that girls could not be distinguished by the way they look like are considered. The issue of humiliation and bullying is considered in both films. Notwithstanding, a separate subject that is not given sufficient attention in the films is the issue of legalized slavery, to which these girls were condemned. 
An important fact is that the last Magdalene Laundry was closed in 1996, which means that until that day, powerless girls, who had their documents taken away and forced to wash their clothes all day long, were imprisoned for almost a whole twentieth century - when the countries of Western Europe promoted the assertion of democratic values. Naturally, the topic of licentiousness was far-fetched and served as a pretext for the exploitation of free labor. Former inmates of the asylums tell the stories of how they worked 14-16 hours a day, and their hands were a bloody mess. At the same time, the main reason for the closure of shelters was not the democratization of society, but the appearance of washing machines.

The main idea of the film Sex in a Cold Climate is to show the stories of girls who went through Magdalene laundries in Ireland, to convey to the viewer the bullying that they had to endure and how these asylums crippled their lives. The main characters in the film are four girls (Brigid Young, Phyllis Valentine, Martha Cooney, Christina Mulcahy), who tell their stories during interviews. Separate comments are given in voice-over. Comments from experts are not provided, so the film takes on the features of a portrait, biographical film, where the main character is collective. The main locations for filming are churches, primarily the icons of St. Magdalene, archival footage of the urban and country areas of Ireland in the 1960s, the laundries inside and outside, rooms of girls in which they gave interviews. The girls told that they could not arrange their family life due to the psychological trauma inflicted on them by the nuns and clergy.

The film conventionally consists of several episodes: 1) Events that became the reason for the imprisonment of girls in laundries, 2) Life in asylums, 3) Liberation and further life. The second episode is the longest and contains honest details of the girls being bullied. One of the girls was cut off only because she talked to the "fallen" girls of the Magdalene asylum. She was shaved by cutting her scalp and face. After the blood flooded her eyes, the nuns forced her to open them and look in the mirror with the words: "You're not so pretty now, are you?" (Humphries, 1998). This scene is well illustrated in the feature film The Magdalene Sisters, as is the subsequent psychological trauma of this girl.

In the last episode of the documentary, the influence of the shelters on the fate of the girls is shown. Brigid Young told: "I didn't see anything godly in that church I didn't see anything Christly. All I saw was a bunch of bullies and devils dressed up in nuns habits. I feel nothing up the Catholic Church". The girl realized that there was no protection in the church, not a place for her. Another inmate Phyllis Valentine also told: "Nuns weren't supposed to be crude. There were Sisters of Mercy, they didn't show us any mercy. They weren't supposed to do what they're done. So I always said if there was a just God in heaven we wouldn't have suffered like that. That was how I put it. When I came out I don't go to church, I don't pray, I don't force religion down my children's throats. I never have done" (Humphries, 1998).

The scenario shape of the film is black and white archival footage and church singing, creating a contrast between the holiness and purity of faith and hypocrisy, cruelty, violence and misanthropy in Catholic asylums. The principle of creating a documentary image, such as typification, is widely used in the film - when reflecting the life of an individual, typical features inherent in his contemporaries are revealed; methods such as typification based on a prototype, creating a psychological image, generalizing the life of a whole generation, evaluating life phenomena by the main character are used. This is because these girls were not the only victims. These are only those who dared to speak, but in their stories, an attentive viewer can see a largescale picture of what was happening.

In the film, the viewer will not see an explicit author's interpretation of the depicted events and self-portraitness (open author's position), the victims build the narrative by themselves and these stories are exhaustive. Among the means of visual documentary expression there is an archival photo and video material, titles. Among the means of audio expression there are the voices of the main characters during interviews and church music. Information gathering methods are an examination of documents and interviews. In general, the film demonstrates a complete picture of slave labor and humiliation of girls, crimes of the Catholic Church in the middle of the twentieth century.

In terms of the rules of journalistic ethics, a lack of objectivity should be mentioned, namely the lack of comments from church representatives. On the other hand, similar interviews in other documentaries (Tell No One, Mea Maxima Culpa: Silence in the House of God) show that the viewer will hear nothing from clerics, but a refutation or an excuse. The lack of imagery of the film, the limited number of expressive cinematographer and director means should also be highlighted. However, the portrait character of the film based on the insight of the value system of girls is fully 
consistent. In this case, the content is more important than the form and the confessional character of the film, the sincerity and openness of the girls provides the essential emotional component.

The main idea of the next film Tell No One (Polish: Tylko nie mów nikomu) 2019 by T. Sekielski (Poland) is to reveal the scale of pedophilia in Polish churches, the obligation of secrecy, which implies mutual guarantee in churches in order to conceal the crimes of priests and protect them from justice. The circle of characters in the film is quite wide: about six victims of sexual violence: A. Czarna, M. Mielewczyk, A. Skrzypkowski; accused priests; clergy commentators; a lawyer Artur Nowak (also a victim of sexual assault in a childhood); doctor; journalists; regional citizens. One of the characters is the authors of the film - director T. Sekielski and cinematographer M. Sekielski, who were directly involved in the action of the film. This allows the film to be classified as a participatory documentary mode, that "took shape with the realization that filmmakers need not disguise their close relationship with their subjects by telling stories or observing events that seemed to occur as if they were not there" (Nichols, 2001: 100-101).

Participatory documentary filmmaking brings the filmmaker closer to the TV reporter, the witness of the event being covered, but at the same time demonstrates the director's interest not only in the publication of an urgent problem, but also in its solution. This mode of documentary "gives us a sense of what it is like for the filmmaker to be in a given situation and how that situation alters as a result. The types and degrees of alteration help define variations within the participatory mode of documentary. When we view participatory documentaries we expect to witness the historical world as represented by someone who actively engages with, rather than unobtrusively observes, poetically reconfigures, or argumentatively assembles that world. The filmmaker steps out from behind the cloak of voice-over commentary" (Nichols, 2001: 100-101). This is exactly what happens in the film by the Sekielski brothers.

The common action of the film is the journey of the protagonists through the provinces of Poland with the aim of meeting with pedophile priests and exposing them, which makes the film affiliated to fiction genre of the road movie. Two main characters: Anna and another victim met their offenders and heard such statements: "why didn't you come with this earlier, I would somehow reward you", "let me give you some money to hide yourself". On the one hand, these scenes demonstrate the uselessness of this action, since the victims receive only another portion of negative emotions from meeting the torturer. On the other hand, from the documentary point of view, this shows that priests do not regret, considering their behavior to be the norm.

Other statements were made from the higher clergy at the Conference of the Polish Episcopate on March 14, 2019. In particular, the chairman of the conference S. Gadecki told: "Looking from the theological point of view, we can say that the point is not that this is the activity of the Devil, this is the act of firstborn sin, that is, some kind of deficiency remains in a person. What we all carry in our nature the desire for good, but also a tendency toward evil. And that eventually results this may be due to the propensity for evil that sleeps in each of us" (Sekielski, 2019).

The film raises a concern carefully hidden from the public - bringing victims of sexual violence to suicide. A. Skrzypkowski, after the abuse, lost faith in humanity and refused to eat. "My childhood collapsed, it just crumbled," Andrzej described. He was already dying when his heart collapsed. Only the move helped him to get better. Another case described in the film ended with self-hanging.

The coverage of locations for filming, typical for a road movie, is also wide enough. These are, first of all, churches (a panoramic demonstration of churches from drone is a scenario shape of the film), streets of different Voivodeships of Poland, houses of priests (filming with a hidden camera), offices, an airport, a car, a cafe, etc. The main episodes of the film are related to the key characters: 1) Anna Czarna, 2) Lawyer, 3) Marek Mielewczyk, 4) Andrzej Skrzypkowski; 5) Attitude to the issue of the church and regional citizens.

The film uses three basic principles of creating a documentary image: typification, author's interpretation, figurative interpretation. Particularly, the open author's position in the film, the self-portraitness of the work should be mentioned. So, based on real facts, the author's point of view is determined, some representations are transformed, new images are created on the basis of representations, the main thematic and illustrative elements are selected, versions are put forward. The director himself acts as a screenwriter and journalist, he interviews regional citizens, makes calls, collects information.

The figurative explanation of the film is also rich, in particular associative images. When the main character Marek Mielewczyk visits the church in which he was corrupted, some of Marek's 
movements are shown in slow motion, the viewer sees Christian attributes and shrines filmed using spectacular cinematography means. Thereby, filmmakers created an image of the hopelessness of a child who could not protect himself from the brutal harassment of the priest, perceiving him as the representative of God on earth. Drops of rain are shown in slow motion, as if all nature had stood still, and time had stopped its passage. Just like time stops for a child who is paralyzed by the feeling of fear. A child tamed by a priest can thus be compared to a fly caught in a sticky web. The scenes shot with a hidden camera, when the victims of molestation came to their rapists to get answers to their questions, have similar features. The priests, quite old age, continued to entangle their already adult victims with hypnotic speeches and smooth movements, hiding behind God and his divine omnipotence.

All of the above applies the film to more than just a participating documentary style, but also to the poetic one, using a wide range of expressive means. Researchers of this style in documentary films specify that the main idea is more often expressed visually, rather than using words, films of this type are more like a work of art than a chronicle: "The poetic mode sacrifices the conventions of continuity editing and the sense of a very specific location in time and place that follows from it to explore associations and patterns that involve temporal rhythms and spatial juxtapositions" (Nichols, 2001: 102).

The film uses a wide variety of visual documentary expression means: a fixed series of events (actions of characters that they conduct during investigations: dialogues, trips, expressed impressions and memories), the environment of the characters (apartment, house, city, country); reproduced event series (reconstruction): events that have already happened that, for objective reasons, could not be filmed (mainly frames from the childhood of the main characters, in particular those that preceded the violence); archival photo and video material, titles. Also, such a technique as going to black is used, which not only allows filmmakers to focus the viewer's attention, but above all - to make a semantic pause and reflect on what the viewer sees. The drone footage creates a contrast between the grandeur of a Catholic church and the insignificance of a victim of violence, between densely populated streets and the loneliness of an outcast person.

The film does an excellent job with sound, uses heartbeat sounds, the noise of the wind and the forest, sounds that reflect the uncomfortable state of the narrator, similar to the sound of an approaching thunderstorm, the creak of iron, the sound of a stretched string, etc. Winter shots of Catholic churches, filmed from a copter, are accompanied by cold tense music typical for such genres of fiction films as thriller, drama, mysticism. The most emotional moments are accompanied by music, which, in accordance with the conceived dramaturgy, either intensifies or fades away. Thus, the viewer hears the voices of the main characters and the voice of the author of the film (in and behind the scenes), synchronous sounds, and special noise effects.

Particularly, the methods of collecting information: observation (with an open camera, a usual camera and a hidden camera) should be mentioned. Such an interesting combination of these techniques gave a good result. An open camera is used for interviews, the usual one for communicating with victims of violence (filming a fixed series of events); a hidden one for filming accused priests and other persons who wished to remain anonymous. By the way, shooting with a hidden camera can be attributed to other methods of collecting information: the method of experiment (creating replicated situations), the method of organized reality. Of course, interviews and the method of studying documents were used.

The next documentary, especially noteworthy, is Alex Gibney's 2012 film Mea Maxima Culpa: Silence in the House of God (UK, USA), which focuses on pedophilia in St. John's School for the Deaf (St. Francis, Milwaukee County, Wisconsin, United States).

The main characters in the film are former pupils of the School: Terry Kohut, Gary Smith, Pat Kuehn, Arthur Budzinski, victims of sexual assault by a priest and former principal Lawrence Murphy. Despite the priority of interviewing the victims, the film cannot be classified as a portrait genre only. This is primarily an investigation film, therefore, to collect information in it, in addition to the main parties of the conflict (pupils and clergy); a huge number of experts were interviewed: a sexologist, a lawyer, journalists etc.

The inside information is very valuable in the film, received in the comments of the journalists of religious periodicals having direct contact with clergy and receiving information from the first hand, as well as the priests who have chosen the scientific and medical path. In one of the comments Benedictine monk and a therapist R. Sipe say: "For a priest, belief in his own goodness can transform, like turning bread into the body of Christ, a perversion into a holy act", "The system 
of the Catholic clergy, for which I have great respect and to which I have given many years of my life, selects, cultivates, protects, defends and produces sexual abusers". Rome Correspondent The Tablet-Catholic Weekly R. Mickens reports the following information: "I still hear some of the old Monsignori in the Vatican, saying, "Oh, boys have always done this, in all-male environments, it's normal. This wasn't abuse, these kids, they were interested, and it's rites of passage". Even in 2011". One more interviewee Canon Lawyer Rev. Thomas Doyle says: "One bishop made the statement, "Little boys heal. They will get over it" (Gibney, 2012).

Among the locations for shooting: St. John's School for the Deaf (archive footage), Catholic churches, offices where interviews took place, the Vatican, Murphy's house. The film itself has more than 10 episodes, which are titled in the film and singled out separate chapters: Lambs of God, The Clerical Sex Therapist, The Fixer, A New Parish, The Whistle blower, The Grand Inquisitor, The Singing Priest, The Reckoning, Omerta (Obligation of Secrecy), Suing the Pope etc. From a dramatic point of view, there are several key chapters. The first of them Lambs of God presents a strong opening of the narrative, acquainting the viewer with the school, students and teachers, social relations of that time. This is a very important chapter that demonstrates the vulnerability of the children in this school. Most parents of deaf children did not know the sign language. Therefore, children could only speak to their parents through a priest (Lawrence Murphy) who knew the language of deaf. They considered him their second father, fought for his attention. Therefore, when the violence happened, the children were seriously injured, but could not tell anyone about it.

The first chapter introduces the viewer to the main antagonist of the story - Murphy. One of the pupils of the school witnessed the crimes of Murphy, comparing him creeping into the boys' bedroom ravenous wolf: "I saw that he was molesting a boy. I imagined Jesus crying on the cross with a broken heart wondering why Murphy was doing this. Why was Jesus just watching?" (Gibney, 2012). So, the crucifixion was one of the images in the film.

The following chapters are an in-depth investigative journalism conducted by the film crew specifically for the film, during which the viewer can hear comments from experts, priests, bishops, archbishops and the Pope himself. These chapters, which are essentially the development of the action of the film, are united by one theme - omerta (obligation of secrecy) - the law of silence, hiding the truth and mutual guarantee among the clergy. In the film, it is proved that it was the higher clergy who forbade disclosing the truth about child abuse in churches, and also refused to take measures to defrock the clergy of guilty priests. There is a document according to which the Pope demanded that all the cases of child molestation be brought to him on the table, that he himself would consider them. Thus, Pope Benedict XVI was the most knowledgeable person in this matter. It is revealed that the Vatican keeps the records of the consuls of Spain of the $4^{\text {th }}$ century, where sexual abuse of children is mentioned. The Church has been aware of this issue for over 1700 years. It also raises the important problem of idealizing the priest in society, when parents beat their children for "slander" against the priest, allowing him to continue to commit crimes.

Another key chapter: The Reckoning, in which Lawrence Murphy's confessions of child molestation are made public: "There was rampant homosexuality among the older boys. I fixed the problem. I thought if I'd play around with a kid once per week they would have their needs met. I thought I was taking their sins on myself. It was sex education for them" (Gibney, 2012). In 1997, former pupils of the school are looking for Lawrence Murphy and demand that he surrender to the police. Of course, this did not happen. However, there is a remarkable scene with a dull housewife Murphy, also a pupil of the School. She chases men away and behaves quite aggressively: "Are you a Catholic?" - he shouted to Bob Bolger. "You should go to church and forgive!" (Gibney, 2012). This confirms several common stereotypes revealed in this film: the reputation of the Catholic Church is placed above the life and health of the laity; a pedophile in the church is considered as a sinner, not a criminal.

From an artistic point of view the last chapter of the film Suing the Pope is quite strong. It reveals the details of the latest lawsuit by the pupils of the school. It also contains a scene of a meeting of former students who thank each other and the lawyer for the help. The viewer sees them as the same little children from the beginning of the film, touching and defenseless, who had to live a hard life. But the strength of the spirit and the will to live defeated despair and fear, they became heroes for the same victims as they were because they found the strength to fight. The film ends cyclically - with grown-up children, a school that is a symbol of a trampled childhood. The school 
and the innocent music that accompanies these shots is the scenario shape for the film. All the interviewed children loved the school and its team, which did not justified their hopes.

Among the principles of creating a documentary image, typification can be highlighted, as the main characters with their stories confirm the existence of the problem of pedophilia in their school, not as an exception to the rules, but as a norm. A large number of interviewed experts demonstrate a wide public resonance of this issue. While many ardent Catholics prefer to close their eyes to this, the public, represented by journalists and human rights activists, are trying to make this problem a subject of wide publicity.

Among the means of visual documentary expression, a fixed series of events (archive footage of 1997, when victims of violence went to Murphy to call him to account) and a reproduced series of events (confessional, boys' bedroom at school) should be mentioned. The reconstruction method is very appropriate in this case. The viewer understands that such shots could not have been filmed; he realizes that this is a reconstruction and does not believe that he is being manipulated. This is rather a vexed problem of documentary filmmaking and the line of viewer trust in the footage seen is very thin. The film actively uses archival material, graphics and titles (thematic chapters).

Speaking about the means of audio documentary expression, two features should be specified. Firstly, the viewer does not see or hear the author of the film, director A. Gibney, either onscreen or offscreen. The author decided to stay on the sidelines, but this does not detract from the scale of his work. Secondly, the deaf-mute heroes of the film were voiced. The viewer hears their voices, and does not read the titles. This is very important both for the perception and for the overall concept of the film. The main characters have found a voice in the literal and figurative sense, thanks to the film they were heard and understood. Music is used very strongly from the dramaturgy point of view. Amateurs often add background music to the entire film, thereby negating all the dramaturgy, while in A. Gibney's film, music is used only at the beginning and at the end of the film. This is a touching innocent melody without words with choral tunes. The technique of silence is also used, silence, allowing the viewer to reflect on the words just heard.

Methods for gathering information include open camera observation, document examination, interviews and reconstruction. The hidden camera method is not used, interviewees openly make contact. This makes the film very different from the Polish film by the Sekielski brothers Tell No One, in which the hidden camera method was prevalent. This testifies to the different formats of documentary filmmaking, as well as to the fact that the Polish Catholic Church is more closed to the media.

\section{Conclusion}

The results of research provide an opportunity to make several conclusions.

First, documentary films are more independent, primarily from budget issues and critical acclaim, therefore a store of issues covered in documentary films is much wider than in fiction. It is necessary to highlight the great freedom of documentary cinema from the fashion trends of our time, in particular, declarative democracy, which puts forward strict requirements for films that claim to receive prestigious film awards.

Secondly, most of the films that claim to be historically accurate are reduced to journalistic investigation, which involves a lot of work with primary sources and with eyewitnesses of events (if possible). In feature films, this investigation is carried out at the stage of pre-production (the stage of preparing the script), and in the case of documentaries, this is carried out both at the stage of preproduction (working with documents) and at the stage of production (interviews, filming, etc.).

Thirdly, the genre of historical drama in feature films is interpreted by directors as close to documentary. Creating feature films in the spirit of documentaries, the authors have reduced the amount of expressive means to a minimum, thereby transforming films from feature films into a chronicle displaying a series of changing facts from the plot of the script, whereas fantasy, mysticism and horror films on the same subject contain a number of stunning special effects, metaphors and associative sequences.

In pursuit of the goal of revealing the historical truth, the authors of feature films imitate documentary films and refuse a number of expressive means, in particular, cinematography techniques, musical accompaniment. They use, first of all, medium (reporter's) and close-ups shooting dispositions, common foreshortenings, the predominance of dialogues. Thus, historical films are primarily based on acting. The viewer also sees limited locations: a school (Doubt), an asylum (The Magdalene Sisters), the editorial office of the magazine The Globe (Spotlight), 
rooms of hotels and houses (Philomena, despite the fact that the film is positioned as a road movie), etc. In contrast to these films, let us recall the historical films of the late twentieth century: Apocalypse Now, The Passion of the Christ, The Last of the Mohicans, Anna and The King, The Messenger: The Story of Joan of Arc, Gladiator, The Patriot, Troy, Kingdom of Heaven, Braveheart, etc., characterized by their epic character and received an Oscar not for following fashion, but for the Best Cinematography, Best Original Score, Best Sound, etc.

All this leads to the fact that the historical genre, despite its authenticity, loses its viewers. At the same time, as more spectacular films attract their audience and in lockstep promote disinformation and manipulation to the masses. According to the analysis results, contemporary documentaries are more art-rich than fiction films in the genre of historical drama. The revision of the principles of work on this genre will enable to reach a new level of feature films.

The prospects for further research lie in a comprehensive study of the morphogenesis of modern historical film; analysis of the dramatic construction of a historical film from the standpoint of the genetic concept of genre analysis; consideration of historical film from the point of view of different classifications of genres and plots; formation of terminology of the newest genres of feature films and documentary.

\section{References}

Amago, 2018 - Amago, S. (2018). Local landscapes, global cinemascapes, and the new galician documentary. Abriu. 7: 81-99. DOI: 10.1344/abriu2018.7.4

Anderson-Lopez et al., 2021 - Anderson-Lopez, J., Lambert, R.J., Budaj, A. (2021). Tug of war: social media, cancel culture, and diversity for girls and the 100. KOME - An International Journal of Pure Communication Inquiry. 9(1): 64-84. DOI: 10.17646/KOME.75672.59.

Bergland et al., 2018 - Bergland, R., Bonwell, A., Gongalla, S., Medapati, S., Heater, H. (2018). Newspapers Vs. TV: Who is taking the most advantage of the www? Online Journal of Communication and Media Technologies. 8(2): 105-116. DOI: 10.12973/ojcmt/2356

Betancourt, 2018 - Betancourt, M. (2018). 'Cinema' as a Modernist Conception of Motion Pictures. AM Journal of Art And Media Studies. 16: 55-67. DOI: 10.25038/am.voi16.254

Bieniek-Tobasco et al., 2020 - Bieniek-Tobasco, A., Rimal, R.N., McCormick, S., Harrington, C.B. (2020). The Power of Being Transported: Efficacy Beliefs, Risk Perceptions, and Political Affiliation in the Context of Climate Change. Science Communication. 42(6): 776-802. DOI: 10.1177/1075547020951794

Canella, 2017 - Canella, G. (2017). Social movement documentary practices: digital storytelling, social media and organizing. Digital Creativity. 28(1): 24-37. DOI: 10.1080/ 14626268.2017.1289227

Cashman, 2019 - Cashman, C.R. (2019). Golden Ages and Silver Screens: The Construction of the Physician Hero in 1930-1940 American Cinema. $J$ Med Humanit. 40(4): 553-568. DOI: 10.1007/s10912-019-09554-0

Clark, 1960 - Clark, K. (1960). Looking at Pictures. New York: Holt, Rinehart and Winston.

Courtney, 2018 - Courtney, S. (2018). Split Screen Nation: Vernacular Screen Forms of the American Paradox. Revue Lisa - Lisa E-Journal. 16. (1). DOI: 10.4000/lisa.9537

Engberg et al., 2020 - Engberg, M., Bolter, J.D. (2020). The aesthetics of reality media. Journal of Visual Culture. 19(1): 81-95. DOI: 10.1177/1470412920906264

Fox, 2018 - Fox, C.F. (2018). The Documentary Films of Jose Gomez Sicre and the Pan American Union Visual Arts Department. ARTMARGINS. 7(3): 34-56. DOI: 10.1162/ARTM _a_00217

Frears, 2013 - Frears, S. (Dir.). (2013). Philomena [Film]. Pathé, Yucaipa Films, BBC Films.

Freeman, 2020 - Freeman, S. (2020). Democracy, religion \& public reason. Daedalus. 149(3): 37-58. DOI: https://doi.org/10.1162/DAED_a_01802

Gibney, 2012 - Gibney, A. (Dir.). (2012). Mea Maxima Culpa: Silence in the House of God [Film]. Jigsaw Productions, Wider Film Projects, Below The Radar Entertainment.

Habel et al., 2018 - Habel, P., Moon, R., Fang, A. (2018). News and information leadership in the digital age. Information Communication \& Society. 21(11): 1604-1619. DOI: 10.1080/ 1369118x.2017.1346136 Films.

Humphries, 1998 - Humphries, S. (Dir.). (1998). Sex in a Cold Climate [Film]. Testimony 
Iacovetti, 2016 - Iacovetti, C. (January 25, 2016). Spotlight: The Burden of Truth. [Electronic Resource]. URL: https://creativescreenwriting.com/spotlight-the-burden-of-truth/

Jesty, 2019 - Jesty, J. (2019). Image pragmatics and film as a lived practice in the documentary work of Hani Susumu and Tsuchimoto Noriaki. Arts. 8(2): 1-18. DOI: 10.3390/arts8020041

Kretz, 2019 - Kretz, V.E. (2019). Television and movie viewing predict adults' romantic ideals and relationship satisfaction. Communication Studies. 70(2): 208-234. DOI: 10.1080/10510974.2019.1595692

McCarthy, 2015 - McCarthy, T. (Dir.). (2015). Spotlight [Film]. Participant Media, First Look Media, Anonymous Content, etc.

McKee, 1997 - McKee, R. (1997). Story: Substance, structure, style and the principles of screenwriting. New York: Regan Books.

Miranda-Galbe et al., 2021 - Miranda-Galbe, J., Cabezuelo-Lorenzo, F., Lopez-Medel, I. (2021). Analytical Model of Transmedia Storytelling Ecosystems in Audiovisual Fiction: The Spanish Model of The Ministry of Time. Communication \& Society. 34(1): 1-13. DOI: 10.15581/003.34.1.1-13

Miyao, 2019 - Miyao, D. (2019). What's the Use of Culture? Cinematographers and the Culture Film in Japan in the Early 1940s. Arts. 8(2): 1-9. DOI: 10.3390/arts8020042.

Mullan, 2002 - Mullan, P. (Dir.). (2002). The Magdalene Sisters. [Film]. Momentum Pictures, Temple Films, PFP Films.

Nakamura, 2020 - Nakamura, L. (2020). Feeling good about feeling bad: virtuous virtual reality and the automation of racial empathy. Journal of Visual Culture. 19(1): 47-64. DOI: $10.1177 / 1470412920906259$

Ness, 2021 - Ness, R. (2021). A Certain Autonomy: Music in the Films of John Huston. Miranda. (22): 1-18. DOI: 10.4000/miranda.39288

Nichols, 2001 - Nichols, K. (2001). Introduction to Documentary. Bloomington: Indiana University Press.

Nietzsche, 1883 - Nietzsche, F. (1883). Thus Spake Zarathustra. A Book for All and None. [Electronic resource]. URL: http://originalbook.ru/thus-spake-zarathustra-f-nietzsche-englishtak-govoril-zaratustra-f-nitsshe/\#google_vignette

Perreault et al., 2019 - Perreault, G., Stanfield, K. (2019). Mobile journalism as lifestyle journalism? Field Theory in the integration of mobile in the newsroom and mobile journalist role conception. Journalism Practice. 13(3): 331-348. DOI: 10.1080/17512786.2018.1424021

Rabiger, 1987 - Rabiger, M. (1987). Directing the Documentary. Waltham: Focal Press.

Rabiger, 2004 - Rabiger, M. (2004). Directing the Documentary. Burlington: Elsevier Inc.

Robison, 2020 - Robison, W.B. (2020). Lancastrians, Tudors, and World War II: British and German Historical Films as Propaganda, 1933-1945. Arts. 9(3): 1-24. DOI: 10.3390/arts9030088

Sekielski, 2019 - Sekielski, T. (Dir.). (2019). Tell No One [Tylko nie mów nikomu]. [Film]. Sekielski Brothers.

Shanley, 2008 - Shanley, J.P. (Dir.). (2008). Doubt [Film]. Miramax Films, Scott Rudin Productions.

Sheehan, 2019 - Sheehan, R.A. (2019). Epistolary form and the displaced global subject in recent films by James Benning and Jem Cohen. Area Abierta. 19(3): 363-381. DOI: 10.5209/arab.63612

Tefertiller et al., 2020 - Tefertiller, A.C., Maxwell L.C., Morris, D.L. (2020). social media goes to the movies: fear of missing out, social capital, and social motivations of cinema attendance. Mass Communication and Society. 23(3): 378-399. DOI: 10.1080/15205436.2019.1653468

Yeo et al., 2018 - Yeo, S.K., Binder, A.R., Dahlstrom, M.F., Brossard, D. (2018). An inconvenient source? Attributes of science documentaries and their effects on informationrelated behavioral intentions. Journal of Science Communication. 17(2): 1-23. DOI: 10.22323/ 2.17020207 